\title{
Pineal Gland Calcification Under Hypoxic Conditions
}

\author{
M. KOPÁNI ${ }^{1}$, B. VRANÍKOVÁ ${ }^{1}$, D. KOSNÁČ ${ }^{1}$, M. ZEMAN ${ }^{2}$, V. ŠIŠOVSKÝ ${ }^{3}$, \\ S. POLAKOVIČOVÁ ${ }^{4}$, C. BIRÓ ${ }^{5}$
}

${ }^{1}$ Institute of Medical Physics, Biophysics, Informatics and Telemedicine, Faculty of Medicine, Comenius University, Bratislava, Slovakia, ${ }^{2}$ Department of Animal Physiology and Ethology, Faculty of Natural Science, Comenius University, Bratislava, Slovakia, ${ }^{3}$ Institute of Pathological Anatomy, Faculty of Medicine, Comenius University, Bratislava, Slovakia, ${ }^{4}$ Institute of Institute of Histology and Embryology, Faculty of Medicine, Comenius University, Bratislava, Slovakia, ${ }^{5}$ Department of Pathology, Institute of Oncology St. Elizabeth, Bratislava, Slovakia

Received July 11, 2019

Accepted October 17, 2019

\section{Summary}

The pineal gland (glandula pinealis) is neuroendocrine gland located at the epithalamus of the brain secreting melatonin. The aim of this study was to explore effects of prenatal hypoxia in rats at the age of 33 weeks on the occurrence of pineal gland calcification. Distribution and chemical composition of calcerous material by light, scanning and transmission electron microscopy was investigated. Melatonin concentrations in blood plasma by direct radioimmunoassay were measured. Rats were exposed to prenatal hypoxia for $12 \mathrm{~h}$ at day 20 of development and second group to prenatal hypoxia for $2 \times 8 \mathrm{~h}$ at days 19 and 20 of development. Vacuoles of intracellular edema in the pineal samples after $12 \mathrm{~h}$ hypoxia were found. Their size ranges up to $30 \mu \mathrm{m}$. Some of them were filled with the flocculent and fibrous material. Samples of pineal glands after $2 \times 8 \mathrm{~h}$ hypoxia revealed the pericellular edema of pinealocytes. The amount of calcium rich particles in $2 \times 8 \mathrm{~h}$ hypoxia group was lower than in $12 \mathrm{~h}$ hypoxia group. Plasma melatonin levels did not differ between control and both hypoxia groups. We concluded that calcification is a process induced by osteoblasts and osteocytes with melatonin as a promotor and it is favored under hypoxic conditions.

\section{Key words}

Pineal gland • Calcification • Electron microscopy • Hypoxia

\section{Corresponding author}

M. Kopáni, Institute of Medical Physics, Biophysics, Informatics and Telemedicine, Faculty of Medicine, Comenius University, Sasinkova 2, 81372 Bratislava, Slovakia. E-mail: martin.kopani@fmed.uniba.sk

\section{Introduction}

The pineal gland (glandula pinealis) is the neuroendocrine gland localized at the epithalamus of the brain and secreting melatonin. This hormone is involved in a control of many physiological processes including control of circadian rhythms, reproductive function in photoperiodic mammals, body temperature, immunity, cardiovascular system and antioxidant activity (Cassone 1990, Reiter et al. 2009, 2010a,b, Tan et al. 1993, Paradies et al. 2010, Chahbouni et al. 2010, DominguezRodriguez et al. 2010). Environmental light/dark (LD) conditions control pineal gland activity (Reiter 1991, Turgut et al. 2008).

Calcium plays an important role in the pineal gland. Neurotransmitter norepinephrine induces both influx and release of $\mathrm{Ca}^{2+}$ from intracellular stores in rat pinealocytes (Saavedra et al. 1973, Saez et al. 1994). Genesis of this material (pineal acervuli) in the pineal gland is a natural process associated with ageing (Schmid and Raykhtsaum 1995; Humbert et al. 1997), endocrine and neuronal diseases, cerebral infarction, symptomatic intracerebral hemorrhage and neuropathologies (Sandyk 1991, 1992a, b, 1993, Bersani 1999). The relationship between pineal calcification and melatonin production is not clear since several studies showed controversial results (Commentz et al. 1986, Bojkowski and Arendt 1990, Kay and Sandyk 1991, Friedland et al. 1990, Turgut et al. 2008). Although the mechanisms of calcification and its biological significance are not well 
understood they are considered to be multifactorial. Two types of calcified granular material are detected in the mammalian pineal gland: 1) the meningeal calcification and 2) the intraparenchymal calcification, which origin relates to the function of pinealocytes (Welsh 1984, Vigh et al. 1992, Lewczuk et al. 1994).

Hypoxia is a condition of the body in which the tissues and cells are deprived of adequate oxygen supply. Hypoxic brain injury is caused by mechanisms such as calcium influx, free oxygen radical formation and apoptosis activation. It was observed that melatonin production by the pinealocytes is significantly reduced (Schmid et al. 1994, Humbert and Pevet 1994, 1995, Coste et al. 2004, Kaur et al. 2007) and it is not known if the decreased pineal melatonin production is related to calcification of the gland.

The aim of this study was to explore effects of hypoxia on the occurrence of pineal gland calcification. Distribution and chemical composition of calcerous material by light, scanning and transmission electron microscopy was investigated. Melatonin concentrations in blood plasma were measured by direct radioimmunoassay.

\section{Methods}

\section{Samples}

The experiments were performed on 24 adult male Wistar rats (Dobra Voda, Slovakia) at the age of 33 weeks. Rats were housed under standard laboratory conditions at LD 12:12, lights on from 08.00 till 20.00 and fed with standard pellet diet and tap water ad libitum. Rats were randomly allocated into three groups. The first group was exposed to prenatal hypoxia for $12 \mathrm{~h}$ at day 20 of development $(n=9)$, the second group to prenatal hypoxia for $2 \times 8 \mathrm{~h}$ at days 19 and 20 of development $(n=5)$ and the third group was the control $(n=10)$. All procedures were conducted in accordance with the Declaration of Helsinki.

Rats were killed by decapitation during the second half of the darktime (between 3.00 and 5.00). Blood was collected to the heparinized tubes and the pineal glands were gently excised. Samples were fixed in $4 \%$ formaldehyde for $24 \mathrm{~h}$, dehydrated in an ascending series of alcohol, cleared with xylene and embedded in paraffin wax. Serially coronal sections were cut on the rotating microtome $(5 \mu \mathrm{m}$ thick) and mounted on silanized slides. Afterward, slides were stained with hematoxylin and eosin and von Kossa according to standard protocol.

\section{Radioimmunoassay}

Melatonin concentrations in blood plasma were measured by direct radioimmunoassay (Zeman et al. 2005). We used melatonin antiserum prepared against $\mathrm{N}$-acetyl-5-methoxy-tryptamine conjugated on bovine thyreoglobuline (Stockgrand Ltd., G/S/ 704-8483, University of Surrey, UK) and tritium labelled melatonin ((O-methyl- $\left.{ }^{3} \mathrm{H}\right)$ Melatonin, TRK 798, specific activity: $3.07 \mathrm{TBq} / \mathrm{mmol}$ (83.0 Ci/mmol), Perkin Elmer, Waltham, MA USA). Sample radioactivity was measured in the scintillating $\beta$-counter for liquid samples (Packard Tri-Carb 2900 TR, Packard Instruments, Perkin Elmer, USA). All samples were measured in a single assay, coefficient of intra-assay was $4.3 \%$.

\section{Light, scanning and transmission electron microscopy}

Samples for SEM + EDX investigation were mounted on carbon block and covered by carbon layer with $30 \mathrm{~nm}$ thickness. SEM analysis was performed by scanning electron microscope EVO LS 15 (ZEISS) with the accelerating voltage of $10 \mathrm{kV}$. Simultaneous EDX line analysis was performed by AMETEK (EDAX) EDS Element Silicon Drift Detector. The time period of spectrum collection was $200 \mathrm{~s}$ with the energy range 0.160 to $10 \mathrm{keV}$.

The samples of pineal gland intended for TEM investigation were fixed in $3 \%$ solution of glutar(di)aldehyde (SERVA, Heidelberg, Germany) for two hours and buffered by phosphate $(\mathrm{pH} 7.2-7.4)$. After dehydration of the tissue by alcohol, the samples were embedded into Durcupan ACM (Fluka AG, Busch, Switzerland) as recommended by the manufacturer and cut

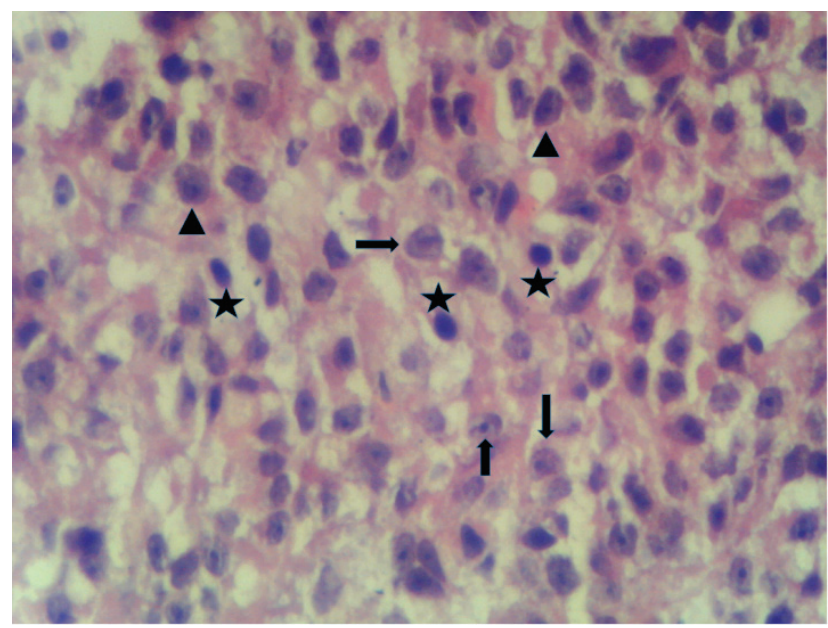

Fig. 1. Pineal gland of rat; the control group. Pinealocytes type 1 are depicted by arrows, pinealocytes type 2 by arrowheads. Glial cells $(G)$ are scattered among pinealocytes and depicted by asterisks. Light microscopy, HE. 40x. 
by ultramicrotome with a glass knife (C. Reichert, Wien, Austria). The thickness of the samples was $100 \mathrm{~nm}$. Contrasted sections with uranyl acetate and lead citrate were mounted on copper grids and investigated by scanning electron microscope EVO LS 15 (ZEISS) with the accelerating voltage of $30 \mathrm{kV}$ in transmission mode.

\section{Results}

Histological investigation of the pineal gland under light microscope showed eosinophilic cytoplasm surrounding the large nuclei. These type of cells were ascribed to pinealocytes type 1 . Pinealocytes type 2 showed pale cytoplasm and small basophilic nuclei. Glial cells, mainly astrocytes, were scattered among pinealocytes. They contained tiny cytoplasm surrounding small deeply-stained elongated nuclei (Fig. 1).

Vacuoles were found in the pineal glands after $12 \mathrm{~h}$ hypoxia and were classified as intracellular edema. Their size reached up to $30 \mu \mathrm{m}$. Some of them were filled with the flocculent and fibrous material. Its size is up to $40 \mu \mathrm{m}$. Large focal calcium-rich particles in both meningeal and intraparenchymal part of pineal gland were found. Smaller calcium rich particles were dispersed in intraparenchymal part of pineal gland (Fig. 2).

Fig. 3 shows samples of pineal glands after $2 \times 8$ h hypoxia. The pericellular edema of pinealocytes was observed. Calcium-rich particles mainly in the meningeal part of the pineal gland were observed with size around $20 \mu \mathrm{m}$. The amount of calcium rich particles in $2 \times 8 \mathrm{~h}$ hypoxia group was lower than in $12 \mathrm{~h}$ hypoxia group (Fig. 3).

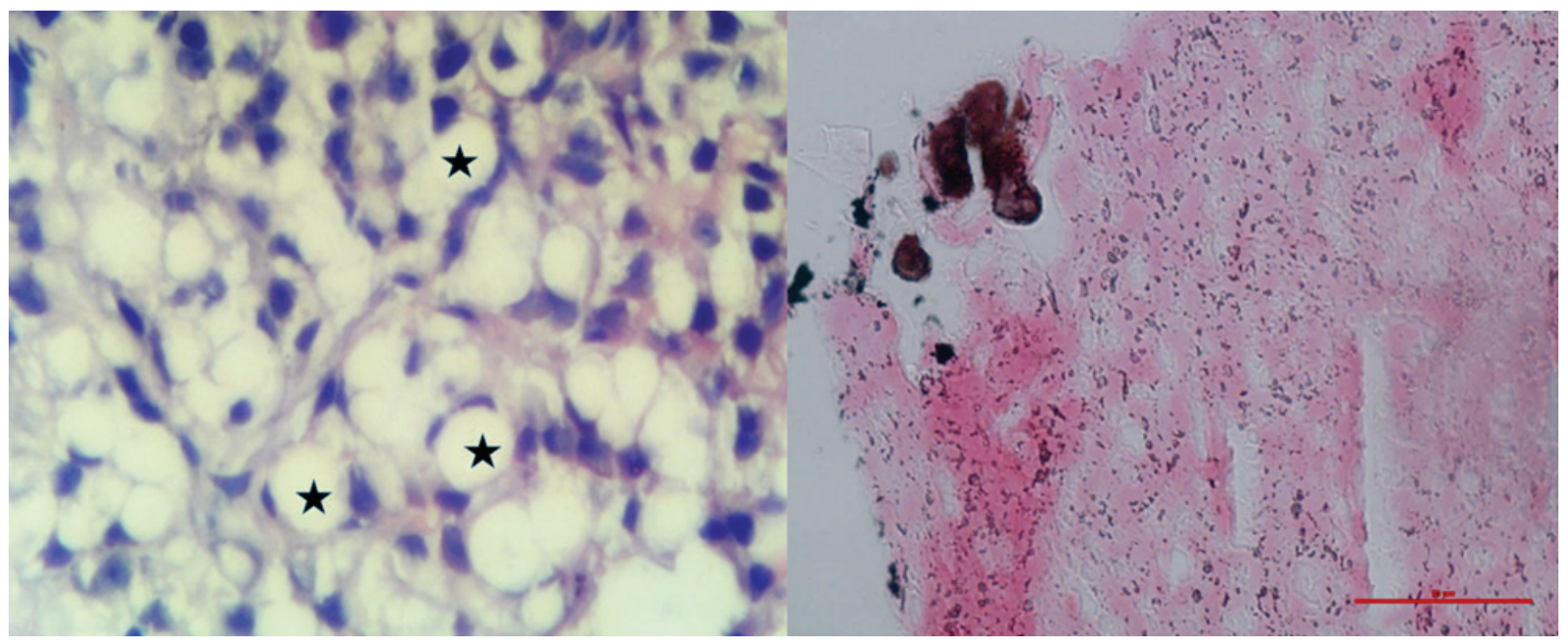

Fig. 2. Pineal gland of rat; $12 \mathrm{~h}$ hypoxia. Left - many vacuoles of intracellular edema of pinealocytes. Right - black dots represent calcium-rich particles in the rat pineal gland. Light microscopy, HE and von Kossa. 40x.
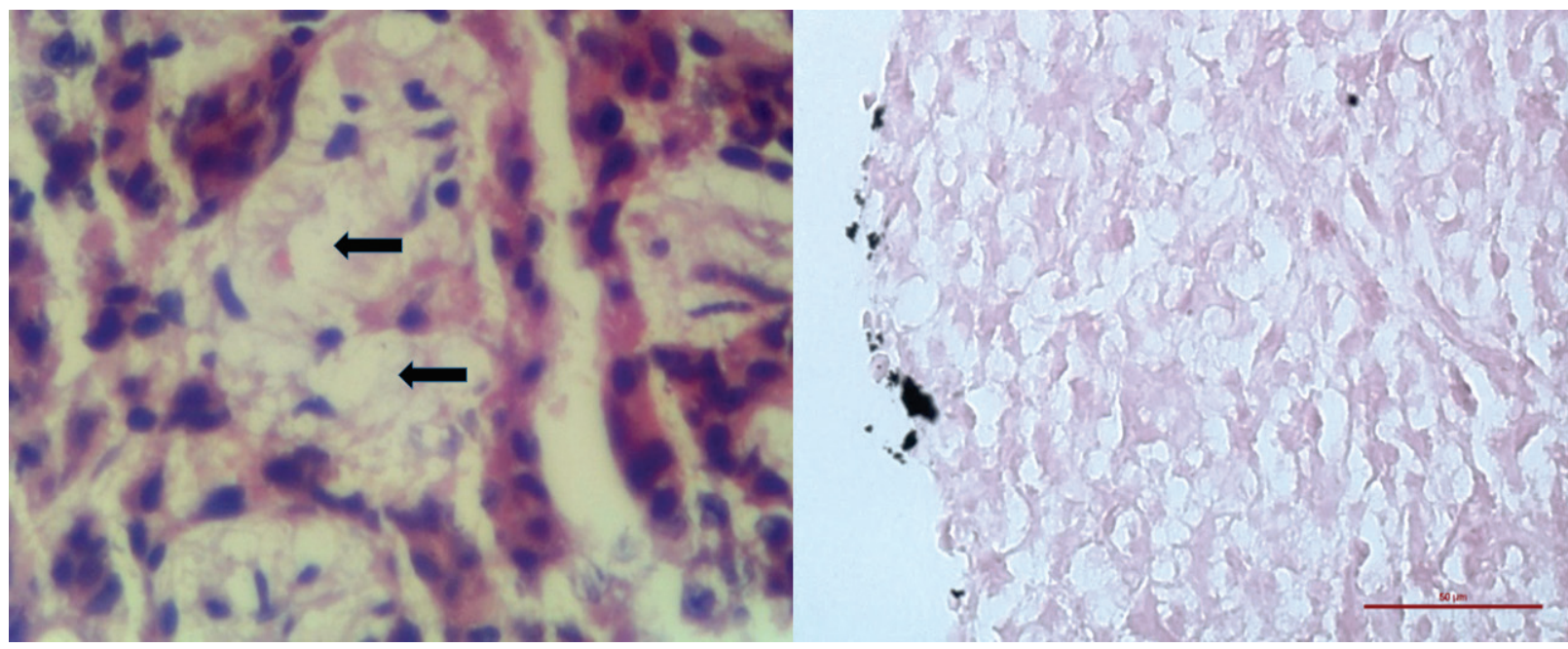

Fig. 3. Pineal gland of rat; $2 \times 8 \mathrm{~h}$ hypoxia. Left - pericellular edema of pinealocytes (arrows). Black dots represent calcium-rich particles in the rat pineal gland. Light microscopy, HE and von Kossa. 40x. 


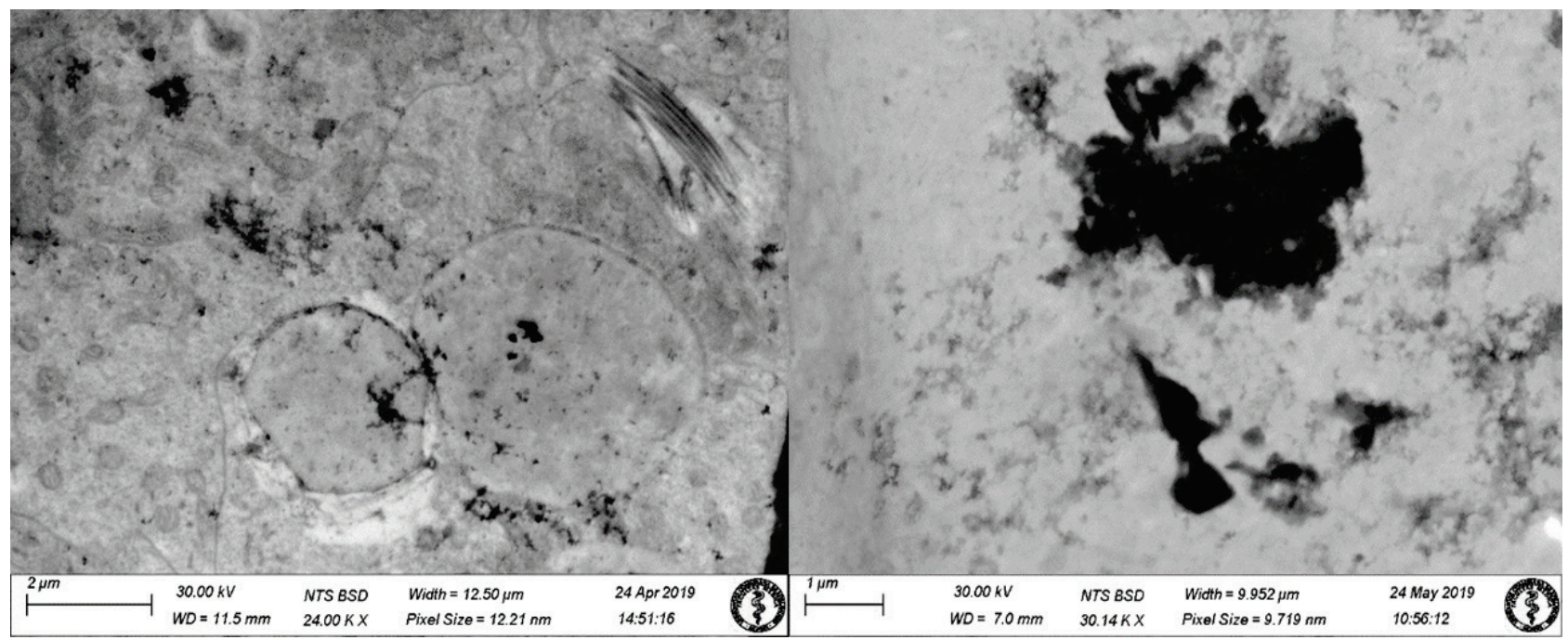

Fig. 4. Pineal gland of rat; $12 \mathrm{~h}$ hypoxia. Left - vacuoles filled with flocculent and fibrous material. Right - extracellular accumulation of flocculent material. Transmission electron microscopy.

Fig. 4 shows vacuoles in the cytoplasm of pinealocytes type I filled with both flocculent and fibrous material in $12 \mathrm{~h}$ hypoxia group. Similar material in intraand extracellular space was observed. Material consists of $\mathrm{Ca}, \mathrm{P}, \mathrm{S}, \mathrm{Na}$.

Plasma melatonin levels, measured in the second part of the dark phase, did not differ between control (mean \pm SD: $87.4 \pm 24.8 \mathrm{pg} / \mathrm{ml}$ ) and both hypoxia groups $(85.0 \pm 16.7$ and $110.1 \pm 39.7 \mathrm{pg} / \mathrm{ml}$ for Hypoxia $12 \mathrm{~h}$ and Hypoxia $2 \times 8 \mathrm{~h}$, respectively.). In all groups, the darktime melatonin levels were higher as compared do those measured in the middle of the light phase (24.3 $\pm 10.9 \mathrm{pg} / \mathrm{ml}$ for control group). It is important to note high inter-individual variability in melatonin concentration in animals was observed.

\section{Discussion}

Pineal gland consists of pinealocytes type 1 and type 2 and glial cells - astrocytes and microglia. Pinealocytes type 1 with the clear nucleus and cytoplasm are described as light and pinealocytes type 2 with dark cytoplasm and nucleus are described as dark pinealocytes (Cernuda et al. 2003). They form the majority of parenchymal cells and are responsible for melatonin production (Kus et al. 2004). Srivastava et al. (1999) according to ultrastructural findings proposed that the light and dark pinealocytes in the pineal gland parenchyma represent different phases of the secretory process. This finding is partially in agreement with Khavinson et al. (2012) who stated that pinealocytes type 1 contain serotonin and pinealocytes type 2 synthesize melatonin from serotonin. On the other hand, Al-Hussain (2006) observed besides the light and dark pinealocytes also a very small cell type with thin and elongated cell body and nucleus. The author suggests high secretory activity of these cells.

It is well known that hypoxia can destroy cells and tissues. Our study confirmed alternations of pineal gland morphology - intra- and pericellular edema in the hypoxia groups. Intracellular edema is caused by changes in the activity of ion channels and transport through the cytoplasmic membrane. These changes leads to intracellular accumulation of water and calcium (Dickey et al. 2011). Intracellular edema is regarded as a premorbid precursor to extracellular (pericellular) edema. Intracellular edema results in osmotic expansion of the cell and depletion the extracellular space of ions and water. This effect creates a new gradient for movement of molecules across the capillary and formation of pericellular edema (Stokum et al. 2015). However, it was observed that the cytoplasm of pinealocytes contains vacuoles filled with flocculent and fibrous material under physiological conditions (Reiter et al. 1976, Humbert and Pevet, 1994, 1995, Schmid and Raykhtsaum 1995, Humbert et al. 1997, Swietoslavski 1999). It is suggested secretory function of vacuoles (Pevet et al. 1977, Haldar and Bishnupuri 2001). Welsh (1984) showed that vacuoles play important role in calcification process. He hypothesized that calcium transported to the vacuoles precipitates into immature concretion. Krstic $(1976,1977,1986)$ proposed that vacuoles and other intracellular structures are the initial calcification sites. The cells gradually degenerated and in 
turn particles are eliminated from the intracellular to the extracellular space.

The localization of vacuoles containing both flocculent and fibrous material in the cytoplasm of pinealocytes is an open question. Some authors observed the presence of vacuoles in pinealocytes type 1 (Welsh and Reiter 1978, Japha et al. 1976). Vacuolation and mineralization are spontaneous morphological changes oin the rat pineal gland as a consequence of cytoplasmatic calcium, which is elevated in the aged cells. However, they were observed also during seasonal and reproductive cycles, with longer exposure to light, confinement to darkness and time of day (Cernuda-Cernuda et al. 2003, Redondo et al. 1996).

On the other hand, Humbert and Pevet (1995) found calcium localized mainly in pinealocytes type 2 with many ultrastructural signs of degeneration. Moreover, they also observed a significant increase in the number of pinealocytes type 2 and a decrease in the total number of pinealocytes with ageing. This decrease of total number of pinealocytes can explain the age-related functional decline of the pineal gland activity. Dark pinealocytes revealed dense cytoplasmic matrix and numerous deposits in the cytoplasm and in nucleus (Pizarro et al. 1989, Schmid et al. 1994, Nakamura et al. 1995). The major chemical elements are calcium and phosphorus with traces of magnesium, zinc and sodium (Zimmermann and Bilaniuk 1982, Kodaka et al. 1994, Nakamura et al. 1995). The calcification process on cell membrane and among pinealocytes was found. Calcium accumulation in the extracellular spaces of the pineal glands of the normal rats were found. In animals sacrificed at midnight accumulations in mitochondrial matrix was observed. After continuous illumination over 7 days, number of these accumulations was lower. In light pinealocytes no intracellular accumulations were found. (Vigh-Teichmann and Vigh, 1992).

Our recent observation revealed in pinealocytes type 1 vacuoles filled with both flocculent and fibrous material consisting of $\mathrm{Ca}, \mathrm{P}, \mathrm{S}$ and $\mathrm{Na}$ and sometimes also $\mathrm{Mg}$ and $\mathrm{Al}$. We also observed this material in both intra- and extracellular space. These findings confirmed changes in the activity of ion channels with subsequent accumulation in the cells and their elimination from the intracellular to the extracellular space. Our present results from light and transmission electron microscopy reveal that calcification does not alter histology of the pinealocytes what is in agreement with findings of Tapp and Huxley (1972).
Hypoxia generates reactive oxygen species (ROS). General response to ROS generation is a rise of antioxidant defense. Concentration of melatonin, as an endogenous antioxidant enhances to the higher level compared to the normal physiological level (Tan et al. 2005), whereas Seifman et al. (2008) did not observed this effect. Higher melatonin production and utilization under hypoxic condition could explain why melatonin concentration did not decrease under hypoxic condition in parallel with altered structure of pinealocytes (vacuoles) and extracellular space (pericellular edema). However, it is necessary to mention that melatonin concentrations were measured only in one point during the darktime. More frequent sampling over the whole $24 \mathrm{~h}$ cycle is needed to reveal possible smaller changes in amplitude and/or acrophase of the melatonin rhythmicity. In our previous study prenatal hypoxia increased blood pressure in mature offspring, especially during the darktime, but did not affect circadian rhythms in cardiovascular parameters (Svitok et al. 2016).

Melatonin may play an essential role in regulating bone growth, bone metabolism, structure and composition. It also regulates production of some proteins and probably prevents from calcium degradation (Ishuzu et al. 2018, Ikegame et al. 2019). Tan et al. (2018) review that calcification of pineal gland is process mediated by mesenchymal stem cells localizing in the pineal gland. Hypoxia-inducible factor (HIF)- $1 \alpha$ increases occurrence of mesenchymal stem cells in the hypoxic areas (Li et al. 2017, Lee et al. 2017, Ciria et al. 2017). These cells can differentiate into osteoblasts and osteocytes with melatonin as a promotor. Melatonin supports mineralization of the pineal gland through upregulation of some proteins (osteopontin, bone morphogenetic protein 2, osteocalcin and alkaline phosphatase). Authors concluded that this process favors calcification under hypoxic conditions. However, it should be mentioned that information regarding the mechanisms underlying development of pineal gland particles and their effects on biological processes are still contraversial (Sandyk and Awerbuch 1994, Schmid et al. 1994, Alcolado et al. 1986, Gerasimov et al. 2014).

Our previous work showed the presence of calcium carbonate crystals in the pineal gland (Tofail et al. 2019). These crystals of the pineal gland have unique properties such as piezoelectricity and can act as an electromechanical biological transducer (Lang et al. 1996, Baconnier et al. 2002). The interaction of the crystals with electromagnetic radiation could influence 
the melatonin production and thus contribute to its circadian control.

\section{Conclusion}

The pineal gland synthesizes melatonin, the important signaling molecule with protective antioxidant activity. The secretory function of the pineal gland can be affected by calcification - deposition of calcium and other ions. The precise mechanism of calcification is still unknown. One theory explains calcification as a process induced by osteoblasts and osteocytes with melatonin as a promotor. Since hypoxia increases occurrence of mesenchymal stem cells the intensity of calcification should be higher. This explanation of calcification process under hypoxic conditions is in agreement with our results therefore we conclude that prenatal hypoxia can promote calcification of the pineal gland.

\section{Conflict of Interest}

There is no conflict of interest.

\section{Acknowledgements}

This work was supported by Slovak Agency for Research and Development - the project No. APVV-16-0039.

\section{References}

ALCOLADO JC, MOORE IE, WELLER RO: Calcification in the human choroid plexus, meningiomas and pineal gland. Neuropathol Appl Neurobiol 12: 235-250, 1986.

AL-HUSSEIN SM: The pinealocytes of the human pineal gland: A light and electron microscopic study. Folia Morphol 65: 181-187, 2006.

BACONNIER S, LANG SB, POLOMSKA M, HILCZER B, BERKOVIC G, MESHULAM G: Calcite microcrystals in the pineal gland of the human brain: first physical and chemical studies. Bioelectromag 23: 488-495, 2002.

BERSANI G, GARAVINI A, TADDEI I, TANFANI G, NORDIO M, PANCHERI P: Computed tomography study of pineal calcification in schizophrenia. Eur Psych 14: 163-166, 1999.

BOJKOWSKI CJ, ARENDT J: Factors influencing urinary 6-sulphatoxymelatonin, a major melatonin metabolite, in normal human subjects. Clin Endocrinol 33: 435-444, 1990.

CASSONE VM: Effects of melatonin on vertebrate circadian systems. Trends Neurosci 13: 457-464, 1990.

CERNUDA-CERNUDA R, PIEZZI RS, DOMUNGUEZ S, ALVAREZ-URIA M: Cell populations in the pineal gland of the viscacha (Lagostomusmaximus). Seasonal variations. Histol Histopathol 18: 827-836, 2003.

CHAHBOUNI M, ESCAMES G, VENEGAS C, SEVILlA B, GARCIA JA, LOPEZ LC, MUNOZ-HOYOS A, MOLINA-CARBALLO A, ACUNA-CASTROVIEJO D: Melatonin treatment normalizes plasma pro-inflammatory cytokines and nitrosative/oxidative stress in patients suffering from Duchenne muscular dystrophy. J Pineal Res 48: 282-289, 2010.

CIRIA M, GARCIA NA, ONTORIA-OVIEDO I, GONZALEZ-KING H, CARRERO R, DE LA POMPA JL, MONTERO JA, SEPULVEDA P: Mesenchymal stem cell migration and proliferation are mediated by hypoxia-inducible factor-1 $\alpha$ upstream of notch and SUMO pathways. Stem Cells Dev 26: 973-985, 2017.

COMMENTZ JC, FISCHER P, STEGNER H, WINKLER P, HELMKE K, WILLIG RP: Pineal calcification does not affect melatonin production. J Neural Transm 21: 481-502, 1986.

COSTE O, BEAUMONT M, BATEJAT D, VAN BEERS P, CHARBUY H, TOUITOU Y: Hypoxic depression of melatonin secretion after simulated long duration flight in man. J Pineal Res 37: 1-10, 2004.

DICKEY WJ, LONG SN, HUNT RW: Hypoxic ischemic encephalopathy - what can we learn from humans? $J$ Vet Inter Med 25: 1231-1240, 2011.

DOMINGUEZ-RODRIGUEZ A, ABREU-GONZALEZ P, SANCHEZ-SANCHEZ JJ, KASKI JC, REITER RJ: Melatonin and circadian biology in human cardiovascular disease. J Pineal Res 49: 14-22, 2010.

FRIEDLAND RP, LUXENBERG JS, KOSS E: A quantitative study of intracranial calcification in dementia of the Alzheimer type. Int Psychogeriatr 2: 36-43, 1990.

GERASIMOV AV, KOSTYUCHENKO VP, SOLOVIEVA AS, OLOVNIKOV AM: Pineal gland as a gravitional lunasensor: manifestation of moon-phase dependent morphologoical changes in mice. Biochem 79: 1069-1074, 2014. 
HALDAR C, BISHNUPURI KS: Comparative view of pineal gland morphology of nocturnal and diurnal birds of tropical origin. Micros Res Tech 53: 25-32, 2001.

HUMBERT W, PEVET P: The decrease of pineal melatonin production with age. Causes and consequences. Ann $N Y$ Acad Sci 719: 43-63, 1994.

HUMBERT W, PEVET P: Calcium concretions in the pineal gland of aged rats: an ultrastructural and microanalytical study of their biogenesis. Cell Tissue Res 279: 565-573, 1994.

HUMBERT W, PEVET P: The pineal gland of the aging rat: Calcium localization and variation in the number pinealocytes. J Pineal Res 18: 32-40, 1995.

HUMBERT W, CUISINIER F, VOEGEL JC, PEVET P: A possible role of collagen fibrils in the process of calcification observed in the capsula of the pineal gland in aging rats. Cell Tissue Res 288: 435- 439, 1997.

IKEGAME M, HATTORI A, TABATA MJ, KITAMURA KI, TABUCHI Y, FURUSAWA Y, MARUYAMA Y, YAMAMOTO T, SEKIGUCHI T, MATSUOKA R, HANMOTO T, IKARI T, ENDO M, OMORI K, NAKANO M, YASHIMA S, EJIRI S, TAYA T, NAKASHIMA H, SHIMIZU N, NAKAMURA M, KONDO T, HAYAKAWA K, TAKASAKI I, KAMINISHI A, AKATSUKA R, SASAYAMA Y, NISHIUCHI T, NARA M, ISEKI H, CHOWDHURY VS, WADA S, IJIRI K, TAKEUCHI T, SUZUKI T, ANDO H, MATSUDA K, SOMEI M, MISHIMA H, MIKUNI-TAKAGAKI Y, FUNAHASHI H, TAKAHASHI A, WATANABE Y, MAEDA M, UCHIDA H, HAYASHI A, KAMBEGAWA A, SEKI A, YANO S, SHIMAZU T, SUZUKI H, HIRAYAMA J, SUZUKI N: Melatonin is a potential drug for the prevention of bone loss during space flight. J Pineal Res 67: e12594, 2019.

ISHIZU H, SEKIGUCHI T, IKARI T, KITAMURA KI, KITANI Y, ENDO M, URATA M, KINOSHITA Y, HATTORI A, SRIVASTAV AK, MISHIMA H, MIZUSAWA K, TAKAHASHI A, SUZUKI N: $\alpha$-Melanocyte-stimulating hormone promotes bone resorption resulting from increased osteoblastic and osteoclastic activities in goldfish. Gen Comp Endocrinol. 262: 99-105, 2018.

JAPHA JL, EDER TJ, GOLDSMITH ED: Calcified conclusions in the superficial pineal gland of the Mongolian gerbil. Acta Anat 95: 533-544, 1976.

KAUR C, SIVAKUMAR V, LU J, LING EA: Increased vascular permeability and nitric oxide production in response to hypoxia in the pineal gland. J Pineal Res 42: 338-349, 2007.

KAY SR, SANDYK R: Experimental models of schizophrenia. Int J Neurosci 58: 69-82, 1991.

KUS I, SARSILMAZ M, ASLANOZEN OA, TURKOGLU AO, PRKMEZ H, SONGUR A, KELESTRIMUR H: Light and electron microscopic examination of pineal gland in rats exposed to constant light and constant darkness. Neuro Endocrinol Lett 25: 102-108, 2004.

KHAVINSON VK, LINKOVA NS, KVETNOY IM, KVETNAIA TV, POLYAKOVA VO, KORF HW: Molecular cellular mechanisms of peptide regulation of melatonin synthesis in pinealocyte culture. Bulletin Exp Biol Med 153: 255-258, 2012.

KODAKA T, MORI R, DEBARI K, YAMADA M: Scanning electron microscopy and electron probe microanalysis studies of human pineal concretions. J Electron Microsc 43: 307-317, 1994.

KRSTIC R: A combined scanning and transmission electron microscopic study and electron probe microanalysis of human pineal acervuli. Cell Tissue Res 174: 129-137, 1976.

KRSTIC R: Ultrastructural and X-ray microprobe comparison of gerbil and human pineal acervuli. Experientia 33: 507-508, 1977.

KRSTIC R: Pineal calcification: its mechanism and significance. J Neural Transm 21: 415-432, 1986.

LANG SB, MARINO AA, BERKOVIC G, FOWLER M, ABREO KD: Piezoelectricity in the human pineal gland. Bioelectrochem Bioenerg. 41: 191-195, 1996.

LEE J, YOON Y, LEE S: Hypoxic preconditioning promotes the bioactivities of mesenchymal stem cells via the HIF-1 $\alpha$-GRP78-Akt axis. Int J Mol Sci 18: 1320, 2017.

LI L, JAISWAL PK, MAKHOUL G, JURAKHAN R, SELVASANDRAN K, RIDWAN K, CECERE R: Hypoxia modulates cell migration and proliferation in placenta-derived mesenchymal stem cells. J Thorac Cardiovasc Surg 154: 543-552, 2017.

LEWCZUK B, PRZYBYLSKA B, WYRZYKOWSKI Z: Distribution of calcified concretions and calcium ions in the pig pineal gland. Folia Histochem Cytobiol 32: 243-249, 1994. 
NAKAMURA KT, NAKAHARA H, NAKAMURA M, TOIKOKA T, KIYOMURA H: Ultrastructure and X-ray microanalytical study of human pineal concretions. Ann Anat 177: 413-419, 1995.

PARAdies, G, PETROSIllo, G, PARADIES, V REITER RJ, RUGGIERO FM: Melatonin, cardiolipin and mitochondrial bioenergetics in health and disease. J Pineal Res 48: 297-310, 2010.

PEVET P, KAPPERS JA, VOUTE AM: The pineal gland of nocturnal mammals I. The pinealocytes of the bat (Nyctalus noctula, Schreber). J Neural Trans 40: 47-68, 1977.

PIZARRO MDL, PASTOR FE, GIL AL, BARRAGAN LM: Ultrastructural study of the distribution of calcium in the pineal gland of the rat subjected to manipulation of the photoperiod. Histochem 92: 161-169, 1989.

REDONDO E, FRANCO AJ, REDONDO S: Prenatal development of the sheep pineal gland: An ultrastructural study. $J$ Pineal Res 21: 140-148, 1996.

REITER RJ, WELSH MG, VAUGHAN MK: Age-related changes in the intact and sympathetically denervated gerbil pineal gland. Am J Anat 146: 427-431, 1976.

REITER RJ: Pineal melatonin: cell biology of its synthesis and of its physiological interactions. Endocrin Rev 12: 151-180, 1991.

REITER RJ, TAN DX, MANCHESTER LC, PAREDES SD, MAYO JC, SAINZ RM: Melatonin and reproduction revisited. Biol Reprod 81: 445-456, 2009.

REITER RJ, TAN DX, FUENTES-BROTO L: Melatonin: a multitasking molecule. Prog Brain Res 181: 127-151, 2010a

REITER, RJ, TAN, DX, PAREDES, SD, FUENTES-BROTO L: Beneficial effects of melatonin in cardiovascular disease. Ann Med 42: 276-285, 2010b.

SAAVEDRA JM, BROWNSTEIN M, AXELROD J: Circadian rhythm of pineal serotonin N-acetyl transferase activity. $J$ Pharmacol Exp Ther 186: 508-519, 1973.

SAEZ JC, MORENO AP, SPRAY DC: Norepinephrine induces Ca $2 \div$ release from intracellular stores in rat pinealocytes. J Pineal Res 16: 57-64, 1994.

SANDYK R, KAY SR: Pineal calcification in schizophrenia. Relationship to age of onset and tardive dyskinesia. Schizophr Res 5: 85-86, 1991.

SANDYK R: Pineal calcification in relation to menopause in schizophrenia. Int J Neurosci 67: 1-8, 1992a.

SANDYK R, KAY SR: Abnormal EEG and calcification of the pineal gland in schizophrenia. Int J Neurosci 62: 107-111, 1992b.

SANDYK R: The relationship of thought disorder to third ventricle width and calcification of the pineal gland in chronic schizophrenia. Int J Neurosci 68: 53-59, 1993.

SANDYK R, AWERBUCH GI: The relationship of pineal calcification to cerebral atrophy on CT scan in multiple sclerosis. Int J Neurosci 76: 71-79, 1994.

SCHMID HA, REQUINTINA PJ, OXENKRUG GF, STURNER W: Calcium, calcification, and melatonin biosynthesis in the human pineal gland: a postmortem study into age-related factors. J Pineal Res 16: 178-183, 1994.

SCHMID HA, RAYKHTSAUM G: Age related differences in the structure of human pineal calcium deposits: results of transmission electron microscopy and mineralographic microanalysis. J Pineal Res 18: 12-20, 1995.

SEIFMAN MA, ADAMIDES AA, NGUYEN PN, VALLANCE SA, COOPER DJ, KOSSMANN T, ROSENFELD JV, MORGANTI-KOSSMANN MC: Endogenous melatonin increases in cerebrospinal fluid of patients after severe traumatic brain injury and correlates with oxidative stress and metabolic disarray._J Cereb Blood Flow Metabol 28: 684-696, 2008.

SRIVASTAVA S: Ultrastructural evidence for the presence of secretory cells in the pineal parenchyma of Heteropneustes fossilis. J Biosci 24: 193-198, 1999.

STOKUM JA, GERZANICH V, SIMARD JM: Molecular pathophysiology of cereberal edeme. J Cereb Blood Flow Metabol 36: 513-538, 2015.

SVITOK P, MOLCAN L, STEBELOVA K, VESELA A, SEDLACKOVA N, UJHAYZ E, MACH M, ZEMAN M: Prenatal hypoxia in rats increased blood pressure and sympathetic drive of the adult offspring. Hypertens Res 39: 501-505, 2016.

SWIETOSLAWSKI J: The age-related quantitative ultrastructural changes in pinealocytes of gerbils. Neuro. Endocrinol Lett 20: 391-396, 1999. 
TAN DX, CHEN LD, POEGGELER BEA: Melatonin: a potent, endogenous hydroxyl radical scavenger. Endocr $J$ 1: 57-60, 1993.

TAN DX, MANCHESTER LC, SAINZ RM, MAYO JC, LEÓN J, REITER RJ: Physiological ischemia/reperfusion phenomena and their relation to endogenous melatonin production: a hypothesis. Endocrine 27: 149-158, 2005.

TAN DX, XU B, ZHOU X, REITER RJ: Pineal calcification, melatonin production, aging, associated health consequences and rejuvenation of the pineal gland. Molecules 23: 1-31, 2018.

TAPP E, HUXLEY M: The histological appearence of the human pineal gland from puberty to ald age. $J$ Pathol 108: 137-144, 1972.

TOFAIL SAM, MOURAS R, MCNAMARA K, PATYK-KAZMIERCZAK E, GEANEY H, ZAWOROTKO M, RYAN KM, SILIEN C, KOPANI M: Multimidal surface analyses of chemistry and structure of biominerals in rodent pineal gland concretions. Appl Surf Sci 469: 378-386, 2019.

TURGUT AT, KARAKAS HM, OZSUNAR Y, ALTIN L, CEKEN K, ALICIOGLU B, SÖNMEZ I, ALPARSLAN A, YÜRÜMEZ B, CELIK T, KAZAK E, GEYIK PÖ, KOSAR U: Age-related changes in the incidence of pineal gland calcification in Turkey: A prospective multicenter CT study. Pathophysiol 15: 41-48, 2008.

VIGH-TEICHMANN I, VIGH B: Immunocytochemistry and calcium cytochemistry of the mammalian pineal organ: a comparison with retina and submammalian pineal organs. Microsc Res Tech 21: 227-241, 1992.

WELSH MG: Cytochemical analysis of calcium distribution in the superficial pineal gland of the mongolian gerbil. J Pineal Res 1: 305-316, 1984.

WELSH MG, REITER RJ: The pineal gland of the gerbil Meriones unguiculatus. I. An ultrastructural study. Cell Tiss Res 193: 323-336, 1978.

ZEMAN M, DULKOVA K, BADA V, HERICHOVA I: Plasma melatonin concentrations in hypertensive patients with the dipping and non-dipping blood pressure profile. Life Sci 76: 1795-1803, 2005.

ZIMMERMANN RA, BILANIUK LT: Age-related incidence of pineal calcification detected by computed tomography. Radiol 142: 659-662, 1982. 


\section{Artifacts in Electron Microscopic Research}

\section{IVAN VARGA ${ }^{1}$, AYMAN GHALLAB ${ }^{2,3}$, LUBOS DANISOVIC ${ }^{4}$}

${ }^{1}$ Institute of Histology and Embryology, Faculty of Medicine, Comenius University in Bratislava, Slovakia, ${ }^{2}$ Department of Histology and Cell Biology, Faculty of Medicine, Zagazig University, Zagazig, Egypt, ${ }^{3}$ British University in Egypt, Cairo, Egypt, ${ }^{4}$ Institute of Medical Biology, Genetic and Clinical Genetic, Faculty of Medicine, Comenius University in Bratislava, Slovakia

Received April 7, 2020

\section{Comment on:}

KOPÁNI M, VRANÍKOVÁ B, KOSNÁČ D, ZEMAN M, ŠIŠOVSKÝ V, POLAKOVIČOVÁ S, BIRÓ C: Pineal gland calcification under hypoxic conditions. Physiol. Res. 68 (Suppl 4): S405-S413, 2019.

\section{Corresponding author}

Ivan Varga, Institute of Histology and Embryology, Faculty of Medicine, Comenius University in Bratislava, Špitalska Street 24, 81372 Bratislava, Slovakia. E-mail: ivan.varga@fmed.uniba.sk

Dear Editor,

We have read with great interest the paper "Pineal gland calcification under hypoxic conditions" authored by Kopáni et al. (2019). The pineal gland is from the morphological point of view a unique organ. Histologically it represents a nervous tissue (pinealocytes are modified neurons and astrocytes are neuroglial cells) but the official morphological nomenclatures (FIPAT 2008; FIPAT 2019) classify this organ as an endocrine gland (in fact, glands are mostly made up of epithelial tissue). The origin and function of the "brain sand" (acervulus, corpus arenaceum) inside the parenchyma of the pineal gland is truly a histological enigma. The degree of calcification is associated with age (more pronounced in elderly patients) and various diseases. However, the presence of calcified concretions seems not to reflect a specific pathological state (Vigh et al. 1998). One hypothesis suggests that the formation of pineal acervulus is a result of a high need for calcium exchange of pinealocytes for their supposed receptor and effector function which is similar to cells of the retina (VighTeichmann and Vigh 1992).

The biggest issue of the article by Kopáni et al. (2019) is a misinterpretation of the pictures from the transmission electron microscope (TEM), so called electron micrographs. TEM is a significant tool in demonstrating the ultrastructure of cells and tissues both in normal and disease states. However, clinical applications of ultrastructural investigation have fallen out of favor recently in number of laboratories since the implementation of immunocytochemical techniques and the development of commercially available monoclonal antibodies (Gunning and Calomeni 2000). Additionally, electron microscopic examination is methodically a very difficult field of morphological research. Every biological or medical scientist in the field of electron microscopy has to deal with the presence of troublesome artifacts caused by various tissue processing procedures. An artifact is a damage caused by a preparation technique and can easily be confused with a genuine ultrastructural finding (Ayache et al. 2010). Unfortunately, these artifacts in electron microscopy and methods of their minimizing have been described only rarely in the scientific literature. Kopáni et al. (2019) probably do not have enough experience with ultrastructural research of human or animal cells and tissues, as they described routinely occurring artifacts as their own and unique results. We divided our comments into five principal areas. 


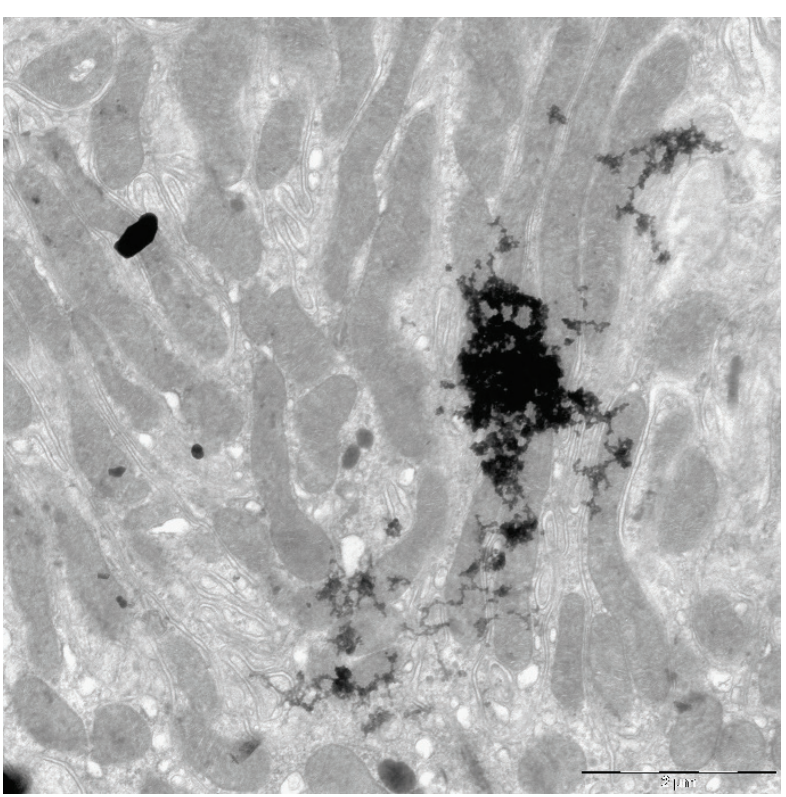

Fig. 1. Example of precipitates of the fixative or contrast agents (lead and uranium artifacts) in a specimen (mitochondria inside a cell of proximal tubule from a kidney are visible).

\section{1) Lead and uranium stain artefacts}

Both presented electron micrographs from the TEM in the article by Kopáni et al. (2019) show artifacts - precipitates of the fixative or contrast agents. These particles are highly electron dense, so it is reasonable to suspect that they may result from the use of heavy metal stains during the processing of tissue for ultrastructural examination (Thaete 1979). Nevertheless, Kopáni et al. (2019) described these, what we deem common findings in electron microscopy research, as "extracellular accumulation of flocculent material". According to our experience, we are more inclined to think that the presented electron micrographs show lead and uranium stains artifacts (Fig. 1). Additionally, according to Vígh et al. (1998), pineal acervulus has concentric lamination of alternating dark and light lines and these lines are not visible in electron micrographs by Kopáni et al. (2019).

\section{2) Formation of "pseudovacuoles" as a compression phenomenon}

Without adequate electron micrographs from the control group of experimental animals (no control results was presented in the discussed electron microscope study), it is too bold to make a conclusion that the cytoplasm of cells contain "vacuoles filled with flocculent and fibrous material". Those vacuoles may represent another artifacts, especially lipid or triglyceride phases that have undergone compression phenomena (during sample preparation the softer phase was poorly embedded). Similar artifact is visible in Figure 2.

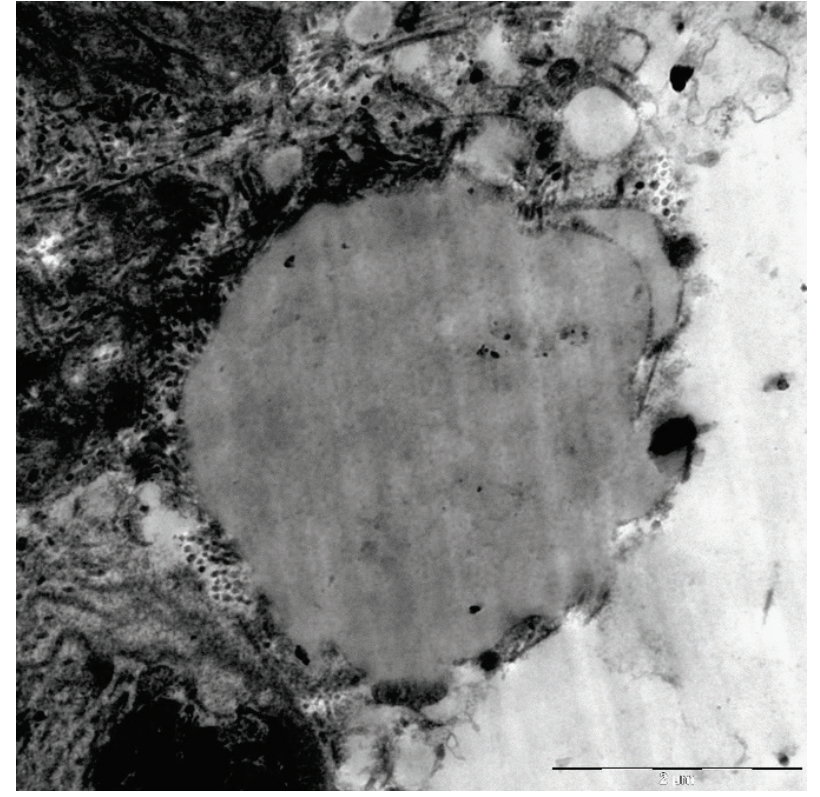

Fig. 2. Example of a "vacuole-like" artifact inside the extracellular matrix of a connective tissue as a result of poorly embedded lipid or triglyceride phases.

\section{3) Lack of experience with ultrastructural description}

Every specialist in histology and cell biology is surprised by the controversial description of the "presence of fibrous material inside intracellular vacuoles". According to Figure 4a from the article by Kopáni et al. (2019), this fibrous material is outside the (pseudo)vacuoles and these fibers are probably normal collagen fibers. So, the authors described the stroma (the connective tissue septa) instead of the parenchyma of the pineal gland. In high magnification, the collagen fibers have typical and well visible cross striations, which can also be seen in the abovementioned figure by Kopáni et al. (2019).

\section{4) Inadequate accelerating voltage}

The accelerating voltage of $100-300 \mathrm{kV}$ remains a good choice for the majority of TEM specimens of typical thickness around $100 \mathrm{~nm}$ (Egerton 2014). Kopáni et al. (2019) used accelerating voltage of $30 \mathrm{kV}$. This low-voltage TEM is attractive for a very thin (e.g. $10 \mathrm{~nm}$ ) specimens, but the thickness of Kopáni's specimens was $100 \mathrm{~nm}$. For this reason the quality of electron micrographs is very poor.

\section{5) Embryological and histological discrepancies}

Last but not least, the newly constructed hypothesis of Kopáni et al. (2019) is also rather dubious. It postulates that the occurrence of brain sand inside the pineal gland is associated with modified function of osteoblasts and osteocytes. This hypothesis is really 
strange. The embryonic origin of the pineal gland is totally different from that of bone cells, so that the process of formation of calcium-rich brain sand is definitely not associated with osteoblasts and osteocytes (these cells are not present inside the pineal gland).

\section{Conclusion}

The early work of Johnson (1983) had described the structure of pineal gland in rat using both light and electron microscopy tools. Unfortunately, the recent study of Kopáni et al. (2019) did not present any good description of pineal gland and the quality of the results is much less than the quality of the early work 40 years ago.

Electron microscopic research is very useful in morphological sciences - in histology, histopathology, cytology or embryology. However, it is also a methodically demanding approach, which requires not only the experienced laboratory staff, but also highly erudite experts who are able to correctly interpret the ultrastructural findings.

\section{Acknowledgement}

Supported by the Slovak Research and Development Agency No. APVV-18-0499.

\section{References}

AYACHE J, BEAUNIER L, BOUMENDIL J, EHRET G, LAUB D: Artifacts in transmission electron microscopy. In: Sample Preparation Handbook for Transmission Electron Microscopy. Springer, New York, 2010.

EGERTON RF: Choice of operating voltage for a transmission electron microscope. Ultramicroscopy 145: 85-93, 2014.

FIPAT (The Federative International Programme for Anatomical Terminology): Terminologia Histologica: International Terms for Human Cytology and Histology. Lippincott Williams \& Wilkins, Baltimore. 2008.

FIPAT (The Federative International Programme for Anatomical Terminology). Terminologia Anatomica. 2nd ed. FIPAT.library.dal.ca 2019.

GUNNING WT, CALOMENI EP: A brief review of transmission electron microscopy and applications in pathology. J Histotechn 23: 237-246, 2000.

JOHNSON JE JR: Histology, ultrastructure, pineal gland, rat. In: Endocrine System. JONES TE, MOHR U, HUNT RD (eds), Springer-Verlag Berlin, 1983, pp 345-355.

KOPÁNI M, VRANÍKOVÁ B, KOSNÁČ D, ZEMAN M, ŠIŠOVSKÝ V, POLAKOVIČOVÁ S, BIRÓ C: Pineal gland calcification under hypoxic conditions. Physiol Res 68 (Suppl 4): S405-S413, 2019.

THAETE LG: Lead and uranium stain artefacts in electron microscopy: a technique for minimizing their occurrence. J Microsc 115: 195-201, 1979.

VÍGH B, SZÉL A, DEBRECENI K, FEJÉR Z, MANZANO E SILVA MJ, VÍGH-TEICHMANN I: Comparative histology of pineal calcification. Histol Histopathol 13: 851-870, 1998.

VIGH-TEICHMANN I, VIGH B: Immunocytochemistry and calcium cytochemistry of the mammalian pineal organ: a comparison with retina and submammalian pineal organs. Microsc Res Tech 21: 227-241, 1992. 


\title{
Reply to Artifacts in Electron Microscopic Research
}

\author{
Martin KOPÁNI ${ }^{1}$, Michal ZEMAN², Štefan POLÁK ${ }^{3}$ \\ ${ }^{1}$ Institute of Medical Physics, Biophysics, Informatics and Telemedicine, Faculty of Medicine, \\ Comenius University, Bratislava, Slovakia, ${ }^{2}$ Department of Animal Physiology and Ethology, \\ Faculty of Natural Science, Comenius University, Bratislava, Slovakia, ${ }^{3}$ Institute of Institute of \\ Histology and Embryology, Faculty of Medicine, Comenius University, Bratislava, Slovakia
}

Received May 15, 2020

\section{Corresponding author}

M. Kopáni, Institute of Medical Physics, Biophysics, Informatics and Telemedicine, Faculty of Medicine, Comenius University, Sasinkova 2, 81372 Bratislava, Slovakia. E-mail: martin.kopani@fmed.uniba.sk

Dear Editor,

We carefully read the comments on our paper "Pineal Gland Calcification under Hypoxic Conditions" (Physiol Res 68 (Suppl 4): S405-S413, 2019) by Varga et al. (this issue); our response is below.

Calcification of the pineal gland has been known for a long time. Our data are in line with the literature and we demonstrated calcification by 3 different techniques: light microscopy, transmission electron microscopy (TEM) and energy-dispersive analysis (EDX) rather than by TEM only, which Varga et al. commented upon. The results of all three methods are consistent. The new findings of our study are related to the effects of prenatal hypoxic conditions on the process of pineal gland calcification. We found that prenatal hypoxia can accelerate the process of calcification, although the biological consequences are still unknown.

The application of contrast agents (uranyl acetate and lead citrate) in electron microscopy can cause the presence of artefacts (electron-dense particles) in the investigated samples. To avoid the misinterpretation of observed particles, EDX analysis was performed. We found particles consisting of $\mathrm{Ca}, \mathrm{P}, \mathrm{S}$, and Na. EDX analysis revealed that the amount of $\mathrm{Ca}$ varied from 0.21 to 20.26 weight $\%$, and the amount of $\mathrm{U}$ from 0.64 to 8.55 weight $\%$. Some particles did not reveal uranium or lead at all. Moreover, some authors observed that the cytoplasm of pinealocytes contains vacuoles filled with flocculent and fibrous material (Humbert et al. 1997, Swietoslavski 1999). From these results, we can conclude that the analyzed electron-dense particles are the result of calcium accumulation and not artefacts.

Biomineralisation (the formation of minerals in the tissue) is a complicated process; the results depend on many factors such as time, the presence of chemical elements and biomolecules, the $\mathrm{pH}$ of the surrounding microenvironment, the presence of water, etc. In this case, the structure (concentric lamination) can be strongly influenced by conditions during the hypoxia. The absence of concentric lamination can reflect these conditions.

Of course, the presence of vacuoles can be the result of compression. However, as we mentioned in our article, many authors observed the presence of vacuoles in the pineal gland under physiological conditions (Reiter et al. 1976, Humbert and Pevet, 1994, 1995, Schmid and Raykhtsaum 1995) and under hypoxia in other tissues (Zeng et al. 2019, Sun et al. 2019, Zhuravin et al. 2003). In addition, the preparation of all samples was the same for all groups and the control group showed almost no vacuoles. Therefore, we conclude that vacuolisation is not the result of compression during preparation but a reaction to the conditions.

We focused on calcium particles and described the fibrous materials inside the vacuoles in the top right corner of Fig. 4. We agree that the fibrous material outside of the vacuoles in the top right corner could be collagen fibres. Tomonari et al. (2012) investigated 383 rats from a histological viewpoint and found focal 
fibrosis on the periphery of the gland; sometimes it was observed in the gland. Therefore, we are convinced that Fig. 4 represents calcification in the parenchyma of the pineal gland.

The whole process of pineal gland calcification is not definitely understood and there are several hypotheses which explain underlying mechanisms. The authors Varga et al. mentioned only one hypothesis suggested by Vigh-Teichmann and Vigh (1992) many years ago. Since then, several other hypotheses have been formulated and are reviewed in a recent paper (Tan et al. 2018). The paper was either not read or pointedly ignored by Varga et al. Our explanation for the increased calcification is based on one of the hypotheses suggested by Tan et al. (2018). We did not deal with all possible hypotheses because this was not the aim of our study.

We found this new hypothesis challenging and our data may support it. Hypoxia is generally accompanied by the generation of reactive oxygen species causing oxidative stress, which promotes the production of different cytokines (Jomova et al. 2010, Pathipati et al. 2013). Cytokines are known to promote the "reprogramming" of mesenchymal cells, as demonstrated many times with different models (Mijiritsky et al. 2020, Krampeta 2011, Zimmermann et al. 2017). In this context, we discussed a possible mechanism for the calcification of the pineal gland in our study. On the basis of above mentioned arguments we are convinced that conclusions of our paper are valid and cannot be questioned.

\section{References}

HUMBERT W, PEVET P: Calcium concretions in the pineal gland of aged rats: an ultrastructural and microanalytical study of their biogenesis. Cell Tissue Res 279: 565-573, 1994.

HUMBERT W, PEVET P: The pineal gland of the aging rat: Calcium localization and variation in the number pinealocytes. J Pineal Res 18: 32-40, 1995.

HUMBERT W, CUISINIER F, VOEGEL JC, PEVET P: A possible role of collagen fibrils in the process of calcification observed in the capsula of the pineal gland in aging rats. Cell Tissue Res 288: 435-439, 1997.

JOMOVA K, VONDRACKOVA D, LAWSON M, VALKO M: Metals, oxidative stress and neurodegenerative disorders. Mol Cell Biochem 345: 91-104, 2010.

KOPANI M, VRANIKOVA B, KOSNAC D, ZEMAN M, SISOVSKY V, POLAKOVICOVA S, BIRO C: Pineal gland calcification under hypoxic conditions. Physiol Res 68 (Suppl 4): S405-S413, 2019.

KRAMPERA M: Mesenchymal stromal cell'licensing': a multistep process. Leukemia 25:1408-1414, 2011.

MIJIRITSKY E, GARDIN C, FERRONI L, LACZA Z, ZAVAN B: Albumin-impregnated bone granules modulate the interactions between mesenchymal stem cells and monocytes under in vitro inflammatory conditions. Mater Sci Eng Mater Biol Appl 110: 110678, 2020.

PATHIPATI P, MULLER S, JIANG XN, FERRIERO D: Phenotype and secretory responses to oxidative stress in microglia. Develop Neurosci 35: 241-254, 2013.

REITER RJ, WELSH MG, VAUGHAN MK: Age-related changes in the intact and sympathetically denervated gebril pineal gland. Am J Anat 146: 427-431, 1976.

SCHMID HA, RAYKHTSAUM G: Age related differences in the structure of human pineal calcium deposits: results of transmission electron microscopy and mineralographic microanalysis. J Pineal Res 18: 12-20, 1995.

SUN SM, WU Y, FU HT, YANG M, GE XP, ZHU J, XUAN FJ, WU XG: Evaluating expression of autophagy-related genes in oriental river prawn Macrobrachium nipponense as potential biomarkers for hypoxia exposure. Ecotoxic Environ Safety 171: 484-492, 2019.

SWIETOSLAWSKI J: The age-related quantitative ultrastructural changes in pinealocytes of gerbils. Neuro Endocrinol Lett 20: 391-396, 1999.

TAN DX, XU B, ZHOU X, REITER RJ: Pineal calcification, melatonin production, aging, associated health consequences and rejuvenation of the pineal gland. Molecules 23: 1-31, 2018.

TOMONARI Y, SATO J, WAKO Y, TSUCHITANI M: Age-related histological findings in the pineal gland of Crl:CD(SD) rats. J Toxicol Pathol 25: 287-291, 2012.

VARGA I, GHALLAB A, DANISOVIC L: Artifacts in electron microscopic research. Physiol Res 69: 537-539, 2020. 
VIGH-TEICHMANN I, VIGH B: Immunocytochemistry and calcium cytochemistry of the mammalian pineal organ: a comparison with retina and submammalian pineal organs. Microsc Res Tech 21: 227-241, 1992.

ZENG L, AI CX, ZHENG JL, ZHANG JS, LI WC: Cu pre-exposure alters antioxidant defense and energy metabolism in large yellow croaker Larimichthys crocea in response to severe hypoxia. Sci Total Environ 687: 702-711, 2019.

ZHURAVIN IA, TUMANOVA NL, DUBROVSKAYA NM, FEDOSEEVA KN: Disturbances in formation of the new and old cortex at changes of conditions of embryonic development. J Evolut Biochem Physiol 39: 752-763, 2003.

ZIMMERMANN JA, HETTIARATCHI MH, MCDEVITT TC: Enhanced immunosuppression of T cells by sustained presentation of bioactiveinterferon-gamma within three-dimensional mesenchymal stem cellconstructs. Stem Cells Transl Med. 6: 223-237, 2017. 